\title{
Endoscopic ultrasound-guided hepatogastrostomy to treat a biliocutaneous fistula
}

We present the case of a 39-year-old woman with a biliocutaneous fistula and a history of surgery for colon cancer. Metastasis to the left lobe of the liver had been detected 3 months before her referral to us and she had been treated with endoscopic retrograde cholangiopancreatography (ERCP)-guided insertion of an uncovered self-expandable metal stent (SEMS; 8-cm long) for obstructive jaundice caused by the metastasis. Postprocedural swelling appeared in the upper abdominal region and subsequently a fistula developed with bilious discharge from the skin over the right upper quadrant, which persisted for 3 months.

She was referred to our clinic with fever; jaundice, abdominal distension, and tenderness were the notable findings on her physical examination. A computed tomography (CT) scan revealed a fistula tract from the left lobe of the liver to the skin, passing through the anterior abdominal wall, with inflammatory changes in the surrounding tissue. After clinical and radiological evaluation, ERCP was performed for the evaluation of the stent but was unsuccessful owing to migration of the SEMS into the common bile duct. After she had completed 3 months of ciprofloxacin therapy, an endoscopic ultrasound (EUS)-guided hepatogastrostomy was performed. A puncture was performed from the stomach to the left intrahepatic bile duct using a 19-gauge needle. The tract was dilated with a bougie, and then a drainage catheter to the stomach (7-Fr, 7-cm biliary plastic stent; Boston Scientific, Marlborough, Massachusetts, USA) was placed ( $\vee$ Video 1 ). The fistula in the upper abdomen was noted to have healed 3 days after performance of the hepatogastrostomy.

Endoscopy_UCTN_Code_CPL_1AK_2AC

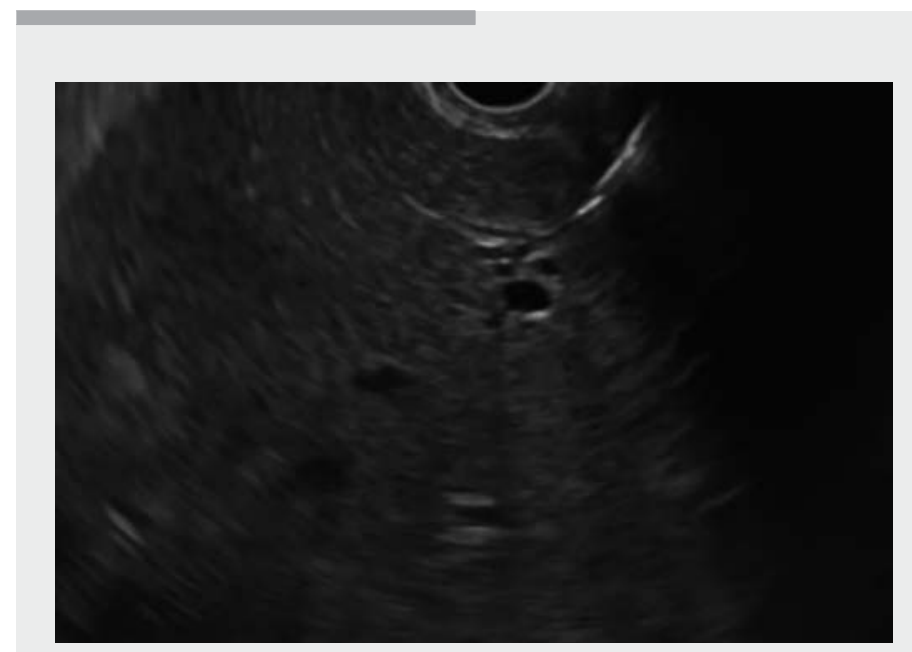

\section{Gurhan Sisman, MD}

Department of Gastroenterology, Acibadem Mehmet Ali Aydinlar University School of Medicine, Halkalı Merkez Mahallesi, Turgut Özal Bulvarı, No:16, Acıbadem Üniversitesi Atakent Hastanesi, Küçükçekmece, Istanbul 34303, Turkey

gurhan.sisman@acibadem.edu.tr
Bibliography

DOI https://doi.org/10.1055/a-1113-7032

Published online: 27.2.2020

Endoscopy 2020; 52: E315

(c) Georg Thieme Verlag KG

Stuttgart · New York

ISSN 0013-726X

ENDOSCOPY E-VIDEOS

https://eref.thieme.de/e-videos

回解 Endoscopy E-Videos is a free access online section, reporting on interesting cases and new techniques in gastroenterological endoscopy. All papers include a high quality video and all contributions are freely accessible online.

This section has its own submission website at https://mc.manuscriptcentral.com/e-videos 